\title{
Kemampuan Predasi Ikan Kepala Timah Aplocheilus panchax Jantan dan Betina Terhadap Larva Nyamuk Aedes aegypti
}

\author{
Jonathan Loody Lukas ${ }^{1}$, Hebert Adrianto ${ }^{2,3}$, Arief Gunawan Darmanto ${ }^{4}$
}

\begin{abstract}
Abstrak
Demam Berdarah Dengue (DBD) masih menjadi masalah utama di Indonesia sampai sekarang. Pemanfaatan ikan kepala timah (Aplocheilus panchax / A. panchax) sebagai pengendali vektor secara biologis bertujuan untuk memutus rantai penularan. Tujuan: Menentukan kemampuan predasi dan keefektifan ikan A. panchax jantan dan betina terhadap larva nyamuk Aedes aegypti. Metode: Penelitian ini menggunakan metode post-test only design. Pengamatan dilakukan dengan menghitung jumlah larva yang dipredasi setiap lima menit hingga 20 larva habis termakan kemudian dianalisis dengan independent sample t-test untuk mengetahui rerata kemampuan predasi kedua kelompok ikan. Hasil: (1) ikan betina memakan rerata 9.20 larva per lima menit sedangkan ikan jantan 7.40 larva per lima menit. (2) ikan betina paling cepat menghabiskan 20 larva nyamuk dalam waktu 6 menit 44 detik sedangkan ikan jantan 9 menit 8 detik. Simpulan: Ikan A. panchax betina lebih efektif dari yang jantan sehingga berpotensi untuk dimanfaatkan sebagai pengendalian vektor DBD.
\end{abstract}

Kata kunci: aplocheilus panchax, aedes aegypti, DBD, pengendalian vektor

\begin{abstract}
Dengue Hemoragic Fever (DHF) is still a major problem in Indonesia until now. The use of white spot fish (Aplocheilus panchax / A. panchax) as a vector controller is biologically aimed at breaking the chain of transmission. Objectives: To determined the predictive ability and effectiveness of male and female A. panchax fish against Aedes aegypti mosquito larvae. Methods: This was the post-test only design. Observations were made by counting the number of larvae that were predetermined every five minutes until 20 larvae were consumed and then statistical analysis of the independent sample t-test to determine the average predation ability of the two groups of fish. Results: (1) female fish ate average 9.20 larvae per five minutes while male fish 7.40 larvae per five minutes. (2) female fish spend 6 minutes 44 seconds to consumed 20 mosquito larvae in while male fish 9 minutes 8 seconds. Conclusion: The female A. panchax fish are more effective than the males so that they have the potential to be used as DHF vector control.
\end{abstract}

Keywords: aplocheilus panchax, aedes aegypti, DHF, vector control

Affiliasi penulis: ${ }^{1}$ Fakultas Kedokteran, Universitas Ciputra, UC Town, Waterpark Boulevard, Citraland CBD, Surabaya, Indonesia. ${ }^{2}$ Departemen Parasitologi, Fakultas Kedokteran, Universitas Ciputra, UC Town, Waterpark Boulevard, Citraland CBD, Surabaya, Indonesia. ${ }^{3}$ Program Doktoral Berbasis Riset, Fakultas Kedokteran, Universitas Airlangga, Surabaya-Indonesia. ${ }^{4}$ Departemen Farmasi Kedokteran, Fakultas Kedokteran, Universitas Ciputra, UC Town, Waterpark Boulevard, Citraland CBD, Surabaya, Indonesia Korespondensi: Hebert Adrianto, Email: hebert.rubay@ciputra.ac.id Telp: 081235245620

\section{PENDAHULUAN}

Demam Berdarah Dengue (DBD) merupakan salah satu penyakit menular endemis di Indonesia. ${ }^{1}$ DBD disebabkan oleh virus dengue dan ditularkan melalui perantaraan serangga nyamuk Aedes yang tersebar luas di seluruh daerah Indonesia sehingga penyakit ini mudah terjadi penularan. ${ }^{2}$ Nyamuk Aedes yang penting di Indonesia sebagai vektor DBD adalah nyamuk Ae. aegypti dan Ae. albopictus. ${ }^{3}$ Profil Kesehatan Indonesia melaporkan jumlah kasus DBD 
di tahun 2019 mencapai 138.127 kasus dengan angka kematian sebanyak 919 jiwa. $^{4}$ Infeksi DBD lebih banyak dialami pada kelompok usia muda (5-14 tahun) setiap tahunnya. ${ }^{5}$

Penyakit DBD masih belum ditemukan obat anti virus maupun vaksin sehingga untuk mengatasi penyebaran penyakit DBD, diprioritaskan pemutusan rantai penularan dengan cara mencegah gigitan nyamuk dan melakukan pengendalian vektor. ${ }^{6}$ Beberapa teknik pengendalian vektor telah dilakukan dengan kimia yaitu menggunakan insektisida namun penggunaannya menimbulkan kerugian pada lingkungan sekitar seperti pencemaran air, meningkatkan resistensi hama, dan menimbulkan racun yang berbahaya (organofosfat) bagi kesehatan dengan cara kontaminasi melalui kontak kulit, terhirup ataupun tertelan. ${ }^{7}$ Beberapa negara telah melaporkan terjadinya resistensi larva nyamuk terhadap temephos. ${ }^{8-10}$

Timbulnya kerugian tersebut memerlukan pengendalian vektor secara biologis yang lebih aman dan ramah lingkungan yaitu dengan memanfaatkan ikan pemakan larva nyamuk. ${ }^{11}$ Salah satu ikan yang memiliki prospek sebagai pengendali larva nyamuk adalah ikan kepala timah (Aplocheilus panchax). Ikan kepala timah dapat ditemukan di kolam, saluran irigasi, kanal, dan bahkan di daerah mangrove dengan air yang jernih dengan tanaman terapung. Manna et al (2011) telah membuktikan bahwa Ikan A. panchax lebih banyak mengkonsumsi larva nyamuk Culex quinquefasciatus dibandingkan cacing tubificid dan larva chironomid. ${ }^{12}$

Ikan $A$. panchax pada penelitian ini memiliki ciriciri umum yaitu bertubuh kecil, memiliki panjang tubuh kira-kira $55 \mathrm{~mm}$, kepala dengan mulut menghadap keatas dan memipih datar di bagian depan, rahang bawah sedikit menonjol dan panjang kepala kira-kira 3,5 kali lebar mata. Perbedaan jenis kelamin dari ikan A. panchax dapat dilihat dari bentuk badan dan warna sisiknya. Bentuk badan ikan jantan lebih langsing dibandingkan ikan betina. Warna sisik pada ikan jantan lebih cerah dan menarik sedangkan ikan betina memiliki warna kusam atau gelap.

Telah dilakukan penelitian sebelumnya mengenai hubungan jenis kelamin terhadap daya predasi ikan Poecilia reticulate terhadap larva Ae. aegypti dan didapatkan perbedaan yang signifikan antara jantan dan betina. ${ }^{13}$ Penelitian ini dapat menjadi acuan untuk memperdalam kemampuan predasi ikan $A$. panchax berdasar jenis kelamin jantan dan betina yang nantinya bertujuan untuk dimanfaatkan sebagai pengendali vektor penyakit DBD.

\section{METODE}

Penelitian ini merupakan studi eksperimen quasi di laboratorium yang dilakukan setelah mendapat persetujuan etik dari Komite Etik Penelitian Kesehatan Universitas Ciputra No. 027/EC/KEPK-FKUC/VII/2019. Ikan $A$. panchax didapatkan di Pasar Ikan Gunung Sari Surabaya. Larva nyamuk Ae. aegypti didapatkan dari Dinas Kesehatan Provinsi Jawa Timur, Surabaya. Larva yang digunakan untuk penelitian adalah larva instar III.

Ikan $A$. panchax mula-mula diukur panjang tubuhnya 3-5 cm dan masing-masing jantan dan betina dimasukkan kedalam akuarium yang berisi akuades sebanyak $1000 \mathrm{ml}$ dan diberi makan pellet dua kali sehari. Aklimatisasi berlangsung selama satu minggu sehingga ikan dapat beradaptasi dengan lingkungan yang baru. Satu hari sebelum dilakukan percobaan, ikan tidak diberi makan sehingga didapatkan kemampuan predasi yang maksimal. Masing-masing jantan dan betina diambil lima ekor dan diletakkan pada sepuluh akuarium yang sudah diberi label jantan 1-5 dan betina 1-5. Larva nyamuk Ae. aegypti instar III baru dibeli tepat pada hari pelaksanaan penelitian. Larva yang dihitung menggunakan handcounter sebanyak 20 ekor dipindahkan ke dalam gelas plastik. Gelas plastik yang berisi larva nyamuk sebanyak 20 ekor dituangkan ke dalam akuarium yang sudah diberi label dan diamati setiap lima menit jumlah larva yang di predasi oleh ikan $A$. panchax kemudian dicatat waktu yang dibutuhkan setiap ikan $A$. panchax untuk menghabiskan 20 ekor larva nyamuk Ae. aegypti instar III.

Data kemampuan predasi ikan $A$. panchax didapatkan dengan cara menghitung larva nyamuk $A e$. aegypti instar III yang dipredasi. Uji analisis data menggunakan Independent Sample T-test untuk mengetahui perbandingan rata-rata jumlah larva yang 
dipredasi oleh ikan $A$. panchax jantan dan betina dalam jangkauan waktu yang sudah ditentukan.

\section{HASIL}

Hasil penelitian didapatkan ikan $A$. panchax betina mampu menghabiskan 20 larva nyamuk $A e$. aegypti dalam waktu 6 menit 44 detik sedangkan jantan menghabiskan 20 larva dalam waktu 9 menit 8 detik. Adapun waktu terlama untuk ikan $A$. panchax betina menghabiskan 20 ekor larva instar III adalah 36 menit 55 detik dan waktu paling lama yang dibutuhkan ikan A. panchax jantan adalah 67 menit 25 detik. Perbandingan rerata jumlah jentik yang dipredasi ikan A. panchax jantan dan betina dapat dilihat pada Gambar dan Tabel.

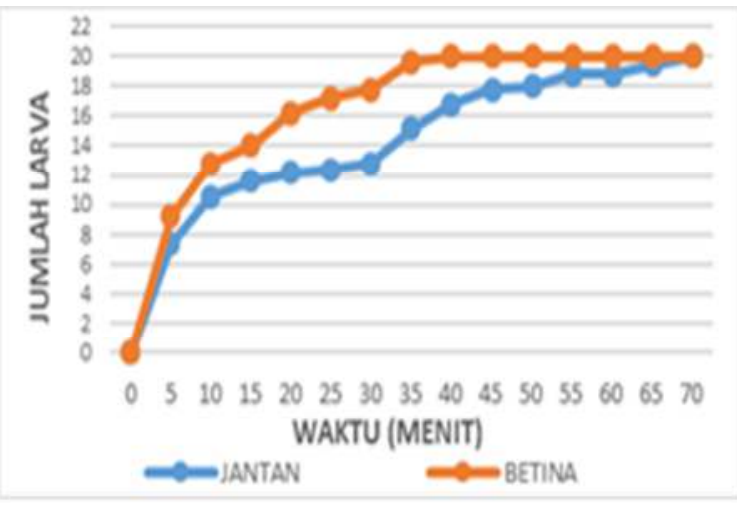

Gambar. Grafik perbandingan rerata jumah larva yang dimakan per lima menit

Tabel. Rerata waktu yang dibutuhkan untuk 20 larva nyamuk

\begin{tabular}{crr}
\hline \multirow{2}{*}{ KELOMPOK } & \multicolumn{2}{c}{ WAKTU PREDASI (menit) } \\
\hline I & Jantan & Betina \\
\hline II & 21 & 6 \\
III & 64 & 36 \\
\hline IV & 67 & 34 \\
\hline V & 9 & 22 \\
\hline Rerata & 43 & 23 \\
\hline Sig. (2-tailed) & $\mathbf{4 0 , 8}$ & $\mathbf{2 4 , 2}$ \\
\hline
\end{tabular}

\section{PEMBAHASAN}

Ikan $A$. panchax dipilih dalam penelitian ini karena memenuhi kriteria ikan yang memiliki daya adaptasi yang baik terhadap habitat atau lingkungan baru atau lingkungan buatan manusia ${ }^{12}$ sehingga perawatan cukup mudah serta dapat mempredasi larva. ${ }^{14}$ Berdasarkan penelitian terdahulu, ikan $A$. panchax merupakan ikan pemakan jentik yang seringkali dimanfaatkan sebagai biokontrol larva nyamuk di Asia. ${ }^{15}$ Efektivitas pemanfaatan ikan $A$. panchax sebagai pengendali vektor DBD yaitu larva nyamuk Ae. aegypti dibuktikan pada penelitian sebelumnya dengan menentukan preferensi makan ikan $A$. panchax terhadap larva nyamuk yaitu Culex quinquefasciatus. $^{12}$

Habisnya 20 ekor larva uji yang dimakan oleh ikan $A$. panchax juga sama dilaporkan oleh Ahmad dan Nurbaeti (2018), yang menguji kemampuan predasi dari ikan hias maanvis (Pterophylium altum) dan ikan hias cuppang (Betta splandens). ${ }^{16}$ Hasil penelitian didapatkan bahwa perbedaan jenis kelamin ikan $A$. panchax berpengaruh terhadap kemampuan predasinya. Grafik perbandingan rerata yang tertera pada Gambar menunjukkan bahwa ikan $A$. panchax betina lebih banyak memakan larva nyamuk pada lima menit pertama daripada jumlah larva yang dimakan ikan A. panchax jantan. Pada menit ke-40 hingga menit ke-70, grafik tidak mengalami perubahan atau stagnant karena pada waktu tersebut tidak ada larva nyamuk yang tersisa pada akuarium sehingga tidak ada aktivitas predasi. Pada garis berwarna biru, terlihat grafik terus menanjak yang menandakan adanya aktivitas predasi ikan $A$. panchax terhadap larva nyamuk Ae. aegypti. Pada Tabel 1. dapat diketahui bahwa rata-rata waktu yang bervariasi bagi ikan $A$. panchax untuk menghabiskan 20 larva nyamuk Ae. aegypti. Waktu yang berbeda-beda disebabkan oleh adanya perbedaan kemampuan predasi yang dipengaruhi oleh usia ikan, ukuran tubuh, kemampuan adaptasi, pencahayaan, suhu ruangan dan luas akuarium. Penelitian Mutmainah menguji daya predasi Ikan Cupang (Betta splendens) dan ikan Guppy (Poecilia reticulate) terhadap larva nyamuk $A e$. aegypti, didapatkan hasil bahwa daya predasi ikan $P$. reticulata pada 1 jam (60 menit) pertama paling banyak adalah 20 ekor. $^{13}$ Jika dibandingkan dengan hasil penelitian ini, ikan $A$. panchax betina memerlukan waktu rata-rata 24,2 menit, dengan waktu tercepat 6 menit dan waktu terlama 34 menit untuk memakan 20 ekor larva. Ikan yang telah diakui oleh dunia sebagai pengendali larva adalah Gambusia 
affinis, G. holbrooki, Claris fuscus, Tilapia nilotica, dan Macropodus sp. ${ }^{17}$ Kedepannya, ikan A. panchax perlu dipertimbangkan dan direkomendasikan sebagai kelompok kontrol biologi.

Tingginya angka DBD memiliki hubungan bermakna dengan kepadatan larva Aedes spp. ${ }^{18-20}$ Larva Aedes sering dijumpai di tempat penampungan air. Nyamuk Aedes memiliki stadium larva dan pupa yang hidup di dalam air sebelum ke tahap dewasa (imago). ${ }^{21}$ Dengan bertemunya ikan dan larva nyamuk, diharapkan ikan akan mempredasi larva nyamuk dan kepadatan larva nyamuk akan berkurang

\section{SIMPULAN}

Ikan $A$. panchax baik betina maupun jantan mampu menghabiskan 20 ekor larva nyamuk Aedes aegypti dalam waktu yang berbeda-beda. Kelompok ikan betina mampu menghabiskan 20 ekor jentik lebih cepat dibandingkan kelompok ikan jantan. Waktu tercepat yang dibutuhkan kelompok ikan betina adalah 6 menit 44 detik, sedangkan kelompok ikan jantan pada waktu 9 menit 8 detik.

\section{UCAPAN TERIMAKASIH}

Terima kasih kepada Unit Layanan di Fakultas Perikanan dan Kelautan Universitas Airlangga yang telah mengidentifikasi ikan uji. Terima kasih juga kepada laboran dan juga penanggung jawab laboratorium yang sudah menyediakan alat dan bahan untuk penelitian ini. Tidak lupa untuk rekan-rekan mahasiswa yang telah membantu penelitan serta pihak lain yang tidak bisa disebutkan satu per satu.

\section{DAFTAR PUSTAKA}

1. Yuningsih R. Kebijakan penanggulangan kejadian luar biasa penyakit demam berdarah dengue di kabupaten Tangerang. Aspir J Masal Sos. 2019;9(2):260-73.

2. Anwar C, Lavita RA, Handayani D. Identifikasi dan distribusi nyamuk Aedes Sp. sebagai vektor penyakit. Majalah Kedokteran Sriwijaya. 2014;46(2):111-7.

3. Wanti W, Sila O, Irfan I, Sinaga E. Transovarial transmission and dengue virus serotypes in Aedes Aegypti In Kupang. J Kesehat Masy.
2016;12(1):131-8.

4. Kementerian Kesehatan Republik Indonesia. Profil Kesehatan Indonesia Tahun 2019 [Internet]. Vol. 42, NASPA Journal. Jakarta: Kementerian Kesehatan Republik Indonesia; 2019 [diakses 2019]. Tersedia dari: https://pusdatin.kemkes.go.id/folder/view/01/struc ture-publikasi-data-pusat-data-dan-informasi.html

5. Suryani ET. Gambaran Kasus Demam Berdarah Dengue di Kota Blitar tahun 2015-2017. J Berk Epidemiol. 2018;6(3):260-7.

6. Ambarita LP, Sitorus H, Rahayu KS, Oktavia S, Ni'mah T, Marini. Efektivitas perangkap berperekat sederhana menggunakan atraktan rendaman jerami terhadap nyamuk di laboratorium. Spirakel. 2019;11(1):8-15.

7. Arif A. Pengaruh bahan kimia terhadap penggunaan pestisida lingkungan. J Chem Inf Model. 2013;53(9):1689-99.

8. De Sá ELR, Rodovalho CDM, De Sousa NPR, De Sá ILR, Bellinato DF, Dias LDS, et al. Evaluation of insecticide resistance in Aedes aegypti populations connected by roads and rivers: The case of tocantins state in Brazil. Mem Inst Oswaldo Cruz. 2019;114(2):1-10.

9. Valle D, Bellinato DF, Viana-Medeiros PF, Lima JBP, Martins Junior ADJ. Resistance to temephos and deltamethrin in Aedes aegypti from Brazil between 1985 and 2017. Mem Inst Oswaldo Cruz. 2019;114(3):1-17.

10. Mulyatno KC, Yamanaka A, Ngadino, Konishi E. Resistance of Aedes aegypti (L.) larvae to temephos in Surabaya, Indonesia. Southeast Asian J Trop Med Public Health. 2012;43(1):29_ 33.

11. Huang YJS, Higgs $S$, Vanlandingham DL. Biological control strategies for mosquito vectors of arboviruses. Insects. 2017;8(21):1-25.

12. Manna B, Aditya G, Banerjee S. Habitat heterogeneity and prey selection of Aplocheilus panchax: An indigenous larvivorous fish. J Vector Borne Dis. 2011;48(3):144-9.

13. Mutmainah S, Prasetyo E, Sugiarti L. Daya predasi ikan cupang (Betta splendens) dan ikan guppy (Poecilia reticulate) terhadap larva instar III nyamuk Aedes aegypti sebagai upaya 
pengendalian vektor penyakit demam berdarah dengue (DBD). J Sains Nat Univ Nusa Bangsa. 2014;4(2):98-106.

14. Jafari $A$, Enayati $A$, Jafari $F$, Motevalli Haghi $F$, Hosseini-Vasoukolaei N, Sadeghnezhad R, et al. A narrative review of the control of mosquitoes by Larvivorous fish in Iran and the world. Iran $\mathrm{J}$ Heal Sci. 2019;7(2):49-60.

15. Chakraborty S, Bhattacharya S, Bhattacharya S. Control of mosquitos by the use of fish in Asia with special reference to India: retrospects and prospects. J Mns dan Lingkung. 2008;15(3):14756.

16. Ahmad $\mathrm{H}$, Nurbaeti. Analisis kemampuan ikan hias maanvis (Pterophylium altum) dan ikan hias cuppang (Betta splandens crow tail) sebagai predator jentik nyamuk. J Sulolipu Media Komun Sivitas Akad dan Masy. 2018;18(1):86-8.

17. Oo NN, Thone MT, Ko MMM, Mya MM. Biological control of Aedes larvae using indigenous fish (Rasbora daniconius (Nga Dawn Zin) and Colisa fasciata (Nga Thit Kyauk)) from Pakokku Township, Magwe Region. J Biol Eng Res Rev. 2018;5(1):1-8.

18. Sari IP, Adrial A, Nofita E. Hubungan kepadatan larva Aedes spp. dengan kejadian demam berdarah dengue di kelurahan Lubuk Buaya kecamatan Koto Tangah Kota Padang. J Kesehat Andalas. 2017;6(1):41-8.

19. Winita R, Prasetyawan A. Indeks kepadatan larva Aedes di Kampus Salemba Universitas Indonesia. eJournal Kedokt Indones. 2018;6(1):53-6.

20. Purnama SG, Baskoro T. Maya Index and larva density Aedes aegypti toward dengue infection. Makara J Heal Res. 2013;16(2):57-64.

21. Martini M, Triasputri $Y$, Hestiningsih R, Yuliawati S, Purwantisasi S. Longevity and development of Aedes aegypti larvae to imago in domestic sewage water. J Med Sci (Berkala IImu Kedokteran). 2019;51(4):325-32. 